\title{
Enlightenment and Erudition: Writing Cultural History at the Académie des inscriptions
}

\author{
Anton M. Matytsin* \\ Department of History, University of Florida \\ ${ }^{\star}$ Corresponding author. E-mail: matytsina@ufl.edu
}

(Received 24 June 2020; revised 31 August 2020; accepted 5 January 2021)

This article explores continuities between the antiquarian erudition of humanist historians and Enlightenment philosophical histories, showing that supposedly revolutionary developments in eighteenth-century historiography emerged from an older scholarly tradition. It focuses on the research of the Royal Academy of Inscriptions and Letters, a learned society in seventeenthand eighteenth-century France that went from serving as a propaganda tool for promoting King Louis XIV's absolutist regime to becoming the first modern historical research institute and a cradle of the Enlightenment. The article examines the emergence of what might be called "cultural history" or "the history of culture" (histoire des moeurs, as eighteenth-century authors called it). It analyzes how the academicians studied pagan beliefs and speculated about the functions of ancient myths and cults, thus transforming the views about the origin of religion and its role in society. The article also discusses how the academicians made sense of customs and daily practices and how they understood the causes of the progress and decline of civilizations.

\section{Introduction: historical writing in the Age of Reason}

The Encyclopédie's "Discours préliminaire" famously distinguished among three different branches of knowledge corresponding to three different faculties of the human mind: "History which is related to memory; Philosophy, which is the fruit of reason; and the Fine Arts, which are born of imagination." " J. G. A. Pocock has observed that Jean Le Rond d'Alembert's encyclopedic tree seemed to relegate "the scholar's enterprise to the lowest of the three rigorously separated capacities of the mind." 2 Indeed, d'Alembert defined memory as "the passive and almost mechanical collection of this same knowledge," suggesting that it was inferior to the other faculties. ${ }^{3}$ He divided the literary world of gens des lettres into three "republics," which were similar to each other only in the "lack of esteem" that their members held for one another: "The poet and the philosopher both treat each other

\footnotetext{
${ }^{1}$ Jean le Rond d'Alembert, "Discours préliminaire des éditeurs," in Denis Diderot and Jean le Rond d'Alembert, eds., Encyclopédie, ou Dictionnaire raisonnée des sciences, des arts et des métiers, 17 vols. (Paris and Neufchatel, 1751-65), 1: i-xlv, at xvi.

${ }^{2}$ J. G. A. Pocock, Barbarism and Religion, vol. 1, The Enlightenments of Edward Gibbon, 1737-1764 (Cambridge, 1999), 202. For Pocock's discussion of the "Discours préliminaire" see 169-207.

${ }^{3}$ D'Alembert, “Discours préliminaire,” xvi.

(c) The Author(s) 2021. Published by Cambridge University Press. This is an Open Access article, distributed under the terms of the Creative Commons Attribution licence (http://creativecommons.org/licenses/by/4.0/), which permits unrestricted re-use, distribution, and reproduction in any medium, provided the original work is properly cited.
} 
as madmen who feed on fancies. Both regard the scholar as a sort of miser who thinks only of amassing facts without enjoying and who indiscriminately heaps up the basest metals along with the most precious ones." ${ }^{4}$ D'Alembert's article "Érudition" in the fifth volume of the Encyclopédie somewhat rehabilitated erudite learning, suggesting that "certain branches of erudition," such as "criticism," were "necessary in the study of sciences." However, he still distinguished between érudition, which he defined as "the knowledge of facts," and science, which was a term "reserved for knowledge that more immediately requires reasoning and reflection, such as physics and mathematics." D'Alembert thus drew a sharp contrast between philosophy and history, between reason and memory-in other words, between enlightenment and erudition.

This tension between natural philosophy and erudite scholarship also led to what Arnaldo Momigliano has described as a clash between "antiquarian" and "philosophic" historians. ${ }^{7}$ Indeed, the apparent distinction between the passive collection of factual knowledge, characteristic of erudite humanism, and philosophical narratives about the progress of human understanding that appeared in the "Discours préliminaire" informed how eighteenth-century philosophes reframed the goals of historical inquiry. In his Essai sur le moeurs (known in English as the Essay on Universal History, the Manners, and Spirit of Nations, 1756), Voltaire declared that the aim of his work was to describe "the spirit, the manners, and the customs of the most considerable nations" and "not to learn in what year a prince unworthy of being known, succeeded to a barbarous sovereign in an uncivilized nation." Focusing on kings "who have improved the manners and contributed to the happiness of their people," Voltaire claimed to present a new kind of history. It was a narrative that depicted the progress of the human mind and the gradual softening of customs. ${ }^{8}$

Swayed by the philosophes' triumphalist rhetoric that stressed the novelty and originality of their approaches to the past, some of the early scholarship about Enlightenment historical writing, beginning with the philosophes themselves and extending into the twentieth century, described a sharp contrast between the antiquarian histories of sixteenth- and seventeenth-century humanists and the philosophical histories of the eighteenth century. In his influential book Voltaire Historian, J. H. Brumfitt has argued that "Enlightenment historiography becomes

\footnotetext{
${ }^{4}$ Ibid., xviii.

${ }^{5}$ Jean le Rond d'Alembert, "Érudition" (1755), in Encyclopédie, 5: 914-18, at 916. For Pocock's interpretation of d'Alembert's article "Érudition" see Barbarism and Religion, 202-7. For alternative discussions of humanist erudition in the Encyclopédie see Dan Edelstein, "Humanism, l'Esprit Philosophique, and the Encyclopédie," Republics of Letters: A Journal for the Study of Knowledge, Politics, and the Arts 1/1 (2009), at https://arcade.stanford.edu/sites/default/files/article_pdfs/roflv01i01_Edelstein_072009_0.pdf.

${ }^{6}$ D’Alembert, "Érudition," 914.

${ }^{7}$ Arnaldo Momigliano, "Ancient History and the Antiquarian," Journal of the Warburg and Courtland Institutes 13/3-4 (1950), 285-315; Momigliano, "Gibbon's Contribution to Historical Method," Historia: Zeitschrift für Alte Geschichte 2/4 (1954), 450-63, at 454, 460.

${ }^{8}$ Voltaire, Essai sur le moeurs et l'esprit des nations, ed. Bruno Bernard, John Renwick, Nicholas Cronk, Janet Godden, and Henri Duranton, in Les oeuvres complètes de Voltaire, 203 vols. (Oxford, 1968-2021), 22: 1-3. For a recent introduction to this text, see Karen Chidwick, Nicholas Cronk, Henri Duranton, Janet Godden, Gianluigi Goggi, Dominique Lussier, Haydn T. Mason, Sylvain Menant, Myrtille MéricamBourdet, Glenn Roe, and Martin Smith, "Introduction générale," in ibid., 21: 5-267.
} 
a reality" with Henry de Boulainvilliers's Histoire de l'ancien gouvernement de France (1727) and Montesquieu's Considérations sur les causes de la grandeur des Romains et de leur décadence (1734), while "the task of interpreting history as a whole from the point of view of the Enlightenment is reserved for Voltaire." In Brumfitt's view, scholars prior to Voltaire "lacked any principle by which they could distinguish fact from fiction and fable," and he dismissed the influence of most of their work. ${ }^{9}$ More recently, Blandine Kriegel's account of historical writing in France has similarly argued that the clash between philosophy and erudition at the dawn of the Enlightenment ended in the definitive "defeat of erudition." She has suggested that d'Alembert's distinction between the barrenness of bookish historical studies and the "fertile garden" of reason consigned the former to the margins of learned culture while promoting the mathematical and physical sciences. The relegation of histoire savante also coincided with a reorientation of the historical discipline as a whole. ${ }^{10}$ Chantal Grell has likewise emphasized the decline of the humanist tradition, citing its inability to "renew itself," and argued that Enlightenment historiography was characterized by an increasingly secular framework. ${ }^{11}$

Scholars have thus tended to define philosophical history as a new, secular, and revolutionary genre made possible by Enlightenment freethinking and explicitly articulated in Voltaire's Histoire de la philosophie (1765). ${ }^{12}$ The genre included works such as Adam Ferguson's An Essay on the History of Civil Society (1767), John Millar's Origin of the Distinction of Ranks (1778), and Nicolas de Condorcet's Esquisse d'un tableau historique des progrès de l'esprit humain (1795), among other texts. Philosophical histories increasingly relied on explanatory factors that no longer referenced divine causes, looking instead to explanations that focused on the environment, material factors, and various human motivations. The genre also articulated conjectural accounts of the earliest societies and offered new narratives about the stadial theories of human development that outlined several stages through which all cultures passed. Philosophical history thus triumphantly depicted the rise of the modern world, focusing on concepts such as civilization, progress, and commercial society. ${ }^{13}$

\footnotetext{
${ }^{9}$ J. H. Brumfitt, Voltaire: Historian (London, 1958), 4.

${ }^{10}$ Blandine Barret-Kriegel, Les historiens et la monarchie, vol. 2, La défaite de l'érudition (Paris, 1988), 307-9.

${ }^{11}$ Chantal Grell, L'histoire entre érudition et philosophie: Étude sur la connaissance historique à l'âge des Lumières (Paris, 1993), 143-51, quotations at 143.

${ }^{12}$ Voltaire, La philosophie de l'histoire (Amsterdam, 1765). This text became the introduction to the Essai sur les moeurs in 1769: Brumfitt, Voltaire: Historian, 85. For more on Voltaire's historical scholarship see Catherine Volpilhac-Auger, "Voltaire and History," in Nicholas Cronk, ed., The Cambridge Companion to Voltaire (Cambridge, 2009), 139-52; Pierre Force, "Voltaire and the Necessity of Modern History," Modern Intellectual History 6/3 (2009), 457-84; John Robertson, "Prefeace," in Voltaire, Essai sur le moeurs et l'esprit des nations, ed. Bruno Bernard, John Renwick, Nicholas Cronk, Janet Godden, and Henri Duranton, in Les oeuvres complètes de Voltaire, 22: xxxvii-xliii; Jean Dagen, "L'histoire 'philosophique' de Voltaire," in Muriel Brot, ed., Les philosophes et l'histoire au xviiie siècle (Paris, 2011), 61-88; Síofra Pierse, "Voltaire: Polemical Possibilities of History," in Sophie Bourgault and Robert Sparling, eds., A Companion to Enlightenment Historiography (Leiden, 2013), 153-87; Antoine Lilti, L'héritage des Lumières: Ambivalences de la modernité (Paris, 2019), 100-10.

${ }^{13}$ For more on philosophical history see Frank E. Manuel, "In Defense of Philosophical History," Antioch Review 20/3 (1960), 331-43; Barret-Kriegel, La défaite de l'érudition, 280-306; Donald R. Kelley, Faces of
} 
It was the disagreement with this sharp distinction between memory, reason, and imagination that, according to Momigliano and Pocock, informed how Edward Gibbon, the most prominent historian of the eighteenth century, started to think about the relationship between erudition and enlightenment. Provoked by "D'Alembert's contempt for erudition," Gibbon "aimed at blending in himself the philosopher and the antiquarian." For the English historian, that connection would prove to be inseparable, and it would deeply inform The Decline and Fall of the Roman Empire (1776-88), in which he "unexpectedly reconciled two methods of writing history which so far had seemed to be inevitably opposed." ${ }^{14}$ Gibbon began this attempt at reconciliation in his Essai sur l'étude de la littérature (1761), where he set out to defend erudition against the attacks of philosophes such as d'Alembert. He appeared uneasy about the way in which d'Alembert relegated memory, history, and antiquarian scholarship to the lowest rank among intellectual endeavors. Gibbon's "project of affirming the intellectual autonomy of l'érudition" was based on his skepticism about the triumphalist narrative of the progress of the human mind and his suspicion of the "hegemony of mathematics" and philosophy. In Pocock's influential interpretation, Gibbon defended the importance of studying history and literature in tandem: he proposed that one could only make sense of texts by "anchoring" them "in their historical contexts," which are discovered by the study "of past states of society and culture, recovered by philosophy and erudition, the exercise of the imagination and the judgment."

Gibbon's unease about the sharp distinction between philosophy and erudition should make us skeptical about the triumphalist depictions of philosophical history as an entirely new form of writing about the past that broke definitively with earlier traditions. Voltaire's polemical Essai sur le moeurs certainly reframed some of the ways in which his contemporaries thought about the history of humankind. However, Voltaire's decision to focus not on particular political events and wars, but on intellectual and cultural history, reflected a by then widespread approach adopted by many eighteenth-century scholars to the study of the past. Similarly, Voltaire's view that history should describe the "progress of the human mind" had already been embraced by a number of historians by the time he set out to write his Essai sur le moeurs. These trends were particularly notable and prevalent at the French Académie royale des inscriptions and belles-lettres. ${ }^{16}$

History: Historical Inquiry from Herodotus to Herder (New Haven, 1998), 217-49; John Burrow, A History of Histories: Epics, Chronicles, Romances, and Inquiries from Herodotus and Thucydides to the Twentieth Century (New York, 2007), 313-44; Guido Abbattista, "The Historical Thought of the French Philosophes," in José Rabasa, Masayuki Sato, Edoardo Tortarolo, and Daniel Woolf, eds., The Oxford History of Historical Writing, vol. 3, 1400-1800 (Oxford, 2015), 406-27; Daniel Woolf, A Concise History of History: Global Historiography from Antiquity to the Present (Cambridge, 2019), 135-42.

${ }^{14}$ Momigliano, "Gibbon's Contribution to Historical Method," 454, 460.

${ }^{15}$ Pocock, Barbarism and Religion, 208-39, quotations at 217, 238.

${ }^{16}$ For more on the Académie royale des inscriptions et belles-lettres see Alfred Maury, L'ancienne Académie des inscriptions et belles-lettres (Paris, 1864); Josèphe Jacquiot, "La fondation et les débuts de l'Académie des inscriptions et belles-lettres," Comptes rendus des séances de l'Académie des inscriptions et belles-lettres 110/1 (1966), 13-14; Lionel Gossman, Medievalism and the Ideologies of the Enlightenment: The World and Work of La Curne de Sainte-Palaye (Baltimore, 1968); Blandine Barret-Kriegel, Les historiens et la monarchie, vol. 3, Les Académies de l'histoire (Paris, 1988), 169-297; Chantal Grell, Le dix-huitième siècle et l'antiquité en France, 1680-1789, 2 vols. (Oxford, 1995), 1: 107- 
There, academicians who studied the cultures of ancient and extra-European societies focused not only on political events and diplomatic relations, but also on artistic achievements, intellectual developments, and daily practices. They explored a variety of past civilizations, examining the gradual changes in the belief structures, cultural activities, and forms of political organization. Voltaire, who in Momigliano's words "abolished footnotes altogether," did not explicitly acknowledge the influence of the Académie des inscriptions for his own writings. ${ }^{17}$ However, his knowledge of antiquity, embrace of global history, and methodological focus all reveal important debts to the research of its members. ${ }^{18}$ Unlike Voltaire, Gibbon made it clear that the academician's erudite studies were instrumental to his formation as a scholar and informed his understanding of the essential connection between enlightenment and erudition. ${ }^{19}$ As Pierre Force has recently argued, Gibbon's "call to combine erudition and philosophy came from within the érudit tradition itself," as members of the Académie des inscriptions such as Nicolas Fréret "showed that it was possible to write ancient history in a way that was intellectually defensible." ${ }^{20}$

The academicians' work, which contemporaries and modern scholars have sometimes dismissed as mere antiquarianism, provided foundational content for Enlightenment theories about human societies. ${ }^{21}$ Their analyses of ancient religions and cults informed critical examinations of revealed religion, including Christianity. Their studies of social customs and practices changed how eighteenth-century philosophers thought about the political, social, economic, and cultural factors that contributed to the rise and fall of empires. The seemingly tedious erudite scholarship of the Academy of Inscriptions thus gradually produced seismic intellectual transformations and served as a cradle of the Enlightenment. ${ }^{22}$

91; Pocock, Barbarism and Religion, 152-68; Robert Wellington, Antiquarianism and the Visual Histories of Louis XIV: Artifacts for a Future Past (Farnham, 2015); Anton M. Matytsin "The Quarrel over Chronology at the Académie des inscriptions: Ancient History, Modern Methods, and the Autonomy of the Historical Discipline," forthcoming in Jacques Bos and Jan Rotmans, eds., The Long Quarrel: Past and Present in the Eighteenth Century (Leiden, 2021).

${ }^{17}$ Arnaldo Momigliano, "The Rise of Antiquarian Research," in Momigliano, The Classical Foundations of Modern Historiography (Berkeley, 1990), 54-79, quotation at 75.

${ }^{18}$ For more on the global turn in eighteenth-century historiography see Alexander Statman, "Fusang: The Enlightenment Story of the Chinese Discovery of America," Isis 107/1 (2016), 1-25; Statman, "The First Global Turn: Chinese Contributions to Enlightenment World History," Journal of Global History 30/2 (2019), 363-92.

${ }^{19}$ Pocock, Barbarism and Religion, 154; and Pierre Force, "The 'Exasperating Predecessor': Pocock on Gibbon and Voltaire," Journal of the History of Ideas 77/1 (2016), 129-45. Gibbon's Decline and Fall is full of references to the Académie's work.

${ }^{20}$ Force, “The 'Exasperating Predecessor'," 134-5.

${ }^{21}$ For notable works on antiquarianism see Arnaldo Momigliano, Essays in Ancient and Modern Historiography (Oxford, 1977); Momigliano, The Classical Foundations of Modern Historiography; Peter N. Miller, ed., Momigliano and Antiquarianism: Foundations of the Modern Cultural Sciences (Toronto, 2007).

${ }^{22}$ For other accounts about the continuity between seventeenth-century historical scholarship and Enlightenment developments see Dmitri Levitin, "Introduction: Confessionalization and Erudition in Early Modern Europe: A Comparative Overview of a Neglected Episode in the History of the Humanities," in Nicholas Hardy and Dmitri Levitin, eds., Confessionalization and Erudition in Early Modern Europe: An Episode in the History of the Humanities (Oxford, 2020), 1-94; Levitin, "What Was 
This article investigates important continuities between antiquarian erudition and Enlightenment philosophy, showing that so-called revolutionary developments in eighteenth-century historical writing emerged from an older scholarly tradition. ${ }^{23}$ The academicians' erudite examinations of past cultures, with a focus on religious beliefs, daily practices, and customs-all broadly defined as moeursreflected a methodological transformation. Their approach to history amounted to what might be called "cultural history" or "the history of culture" (histoire des moeurs, as eighteenth-century authors called it) that explored how those different beliefs and practices contributed to the functioning of past societies. ${ }^{24}$ Their work was crucial to the development of the genre of philosophical history, for which it uncovered new materials and offered novel explanatory modes. Their studies shaped how other historians analyzed the complex elements that contributed to the rise and decline of ancient and modern civilizations, leading their contemporaries and their heirs to think more critically and self-reflexively about the age in which they lived. The academicians' erudite research thus provided the intellectual raw materials for subversive Enlightenment critiques of religious and political authorities.

\section{The origins of the Académie des inscriptions et belles-lettres}

The Académie was established at the dawn of the age of Louis XIV. The Sun King was waging wars of expansion in Europe, seeking to cement his absolutist rule in a country that had suffered a series of civil wars at the beginning of his reign, and building the palace of Versailles. France's imperial ambitions spread armies, scholars, and missionaries all over Europe, Asia, Africa, and the Americas. These agents of empire returned with new commodities and new knowledge in the form of texts and artefacts. Louis and Jean-Baptiste Colbert, the superintendent of royal buildings and the controller-general of finances, sought to turn France into the

the Comparative History of Religions in 17th-Century Europe (and Beyond)? Pagan Monotheism/Pagan Animism, from T'ien to Tylor," in Renaud Gagné, Simon Goldhill, and Geoffrey E. R. Lloyd, eds., Regimes of Comparatism: Frameworks of Comparison in History, Religion, and Anthropology (Leiden, 2019), 49-115.

${ }^{23}$ For other discussions of Enlightenment historical writing see Grell, L'histoire entre érudition et philosophie; Johnson Kent Wright, "Historical Thought in the Era of the Enlightenment," in Lloyd Kramer and Sara Maza, eds., A Companion to Western Historical Thought (Oxford, 2002), 123-42; Anthony T. Grafton, What Was History? The Art of History in Early Modern Europe (Cambridge, 2007); J. G. A. Pocock, "Historiography and Enlightenment: A View of Their History," Modern Intellectual History 5/1 (2008), 83-96; Muriel Brot, ed., Les philosophes et l'histoire au XVIIIe siècle (Paris, 2011); Sophie Bourgault and Robert Sparling, eds., A Companion to Enlightenment Historiography (Leiden, 2013); Abbattista, "The Historical Thought of the French Philosophes." For an analysis of continuities in natural philosophy see J. B. Shank, "European Tellings of the World's Beginnings around 1700: Between Religion, Prose, Verse, and Scripture, and Image and Text" (forthcoming).

${ }^{24}$ For other accounts of the early origins of cultural history see Donald R. Kelley, "Writing Cultural History in Early Modern Europe: Christophe Milieu and His Project," Renaissance Quarterly 52/2 (1999), 342-65; Peter N. Miller, "Taking Paganism Seriously: Anthropology and Antiquarianism in Early Seventeenth-Century Histories of Religion," Archiv für Religionsgeschichte 3 (2001), 183-209; Michael C. Carhart, The Science of Culture in Enlightenment Germany (Cambridge, MA, 2008); Anthony T. Grafton, "Comparisons Compared: A Study in the Early Modern Roots of Cultural History," in Gagné, Goldhill, and Lloyd, Regimes of Comparatism, 18-48. 
preeminent military and cultural power, importing technical experts, artists, authors, and institutions from all over Europe. The Academy of Inscriptions was established alongside the Academy of Sciences and the Academy of Fine Arts, based on private Italian learned societies of the sixteenth and seventeenth centuries. The academies became an important tool in the centralization of royal patronage while simultaneously fulfilling the needs of the growing administrative state. ${ }^{25}$ In Colbert's mind, the academies would help the French Crown harness knowledge in service of political control, a phenomenon that Jacob Soll has called érudition d'état. $^{26}$ Colbert saw information gathering as essential to strengthening the power of the Crown and of the state, and history was to serve a major part in this project. ${ }^{27} \mathrm{He}$ dispatched agents all over France to gather documents and charters in local archives, and he also sent some scholars as far as the Ottoman Empire to collect manuscripts, books, and artefacts. ${ }^{28}$ Some of the academicians, such as Nicolas-Joseph Foucault, also proved instrumental in overseeing the Crown's repressions of Huguenots prior to and following the revocation of the Edict of Nantes in $1685 .^{29}$

The Académie was thus Colbert's brainchild, and it played an important part in the Crown's image-making campaign as "a historical research team for political propaganda." 30 Louis XIV fashioned himself as the reincarnation of the Greek god Apollo, Alexander the Great, and the Roman emperor Augustus, in challenging other European monarchs for primacy on the world stage. ${ }^{31}$ Seeking to provide historically informed representations of Louis XIV (with heroic images and statues that filled the halls of Versailles), Colbert founded the Little Academy (la Petite académie) in 1663. The inaugural members Jean Chapelain, Amable de Bourzeis, Jacques Cassagne, and François Charpentier-all prominent members of the Académie française-met in Colbert's library, initially without an official charge or mission statement.

The Little Academy's members received generous pensions. They were charged with locating ancient monuments, coins, medals, and inscriptions that could be used as models for commemorating the military triumphs and achievements of the Sun King. They were "responsible for the public image of the king, and as the creators of objects that would long outlast him, their works would hold an

\footnotetext{
${ }^{25}$ For more on the Académie des sciences see Alice Stroup, A Company of Scientists: Botany, Patronage, and Community at the Seventeenth-Century Parisian Royal Academy of Sciences (Berkeley, 1990); David J. Sturdy, Science and Social Status: The Members of the Académie des Sciences, 1666-1750 (Rochester, 1995); J. B. Shank, Before Voltaire: The French Origins of "Newtonian" Mechanics, 1680-1715 (Chicago, 2018).

${ }^{26}$ Jacob Soll, The Information Master: Jean-Baptiste Colbert's State Intelligence System (Ann Arbor, 2009), 9. For more on Soll's account of Colbert's role in establishing the Académie des inscriptions see ibid., 9-12, $25-7,100-13,123-30$.

${ }^{27}$ Orest A. Ranum, Artisans of Glory: Writers and Historical Thought in Seventeenth-Century France (Chapel Hill, 1980).

${ }^{28}$ Alexander Bevilacqua, The Republic of Arabic Letters: Islam and the European Enlightenment (Cambridge, MA, 2018), 17-38.

${ }^{29}$ Soll, The Information Master, 123-7. See also Jacob Soll, "How Islam Shaped the Enlightenment," New Republic, 18 April 2018, at https://newrepublic.com/article/147961/islam-shaped-enlightenment.

${ }^{30}$ Soll, The Information Master, 128.

${ }^{31}$ Peter Burke, The Fabrication of Louis XIV (New Haven, 1992).
} 
enduring influence over his memory." ${ }^{32}$ One of the academy's first projects was the publication of a historical account of Louis XIV's reign in medals. The academicians designed these medals, describing the events they commemorated for posterity. ${ }^{33}$ They also collected documents to support the Crown's legal claims over the church and the nobility.

The academy's connection to the Crown's project of state building and the centralization of royal authority thus revealed the extent to which the Republic of Letters was connected to what Jacob Soll has called "the dialectic between learning and power." 34 This dialectical relationship extended from the sixteenth century and the foundation the Bibliothèque royale under Guillaume Budé to the eighteenth century, when the state used the royal academies founded under Louis XIV to solidify a monopoly on patronage. As Dan Edelstein has observed, the state thus became "the necessary sponsor of the Enlightenment," as "there was a basic convergence between the French Crown and the philosophes." 35 The entanglements between erudition and absolutism thus reveal the complex origins of Enlightenment learned culture and the tensions inherent in modern disciplinary structures and academic institutions.

Originally composed of only five scholars who met in Colbert's house, the academy expanded to forty members over its first forty years and became an official institution of the French state. In 1691, when Louis Phélypeaux II, compte de Pontchartrain, the future Chancellor of France, came to oversee the work of the royal academies, he instituted a number of important administrative changes. His nephew Jean-Paul Bignon was appointed inaugural president of the Academy of Sciences, and he quickly helped to make it the preeminent institution of scientific learning in Europe. This was a moment when, according to J. B. Shank, the Academy of Sciences turned into "a more emphatically administrative institution than it had previously been" and was transformed "into the protoprofessional and publicly oriented institution that would become its hallmark during the French Enlightenment."36

Bignon's reforms at the Académie des sciences would serve as a blueprint for the changes he would bring about at the Petite académie. The structure and the procedures of the Little Academy became more formalized under Bignon's leadership, and, in 1701, it was officially reconstituted and gained the title of the Académie royale des inscriptions et médailles. This official recognition was accompanied by a formal constitution that included a total of forty-nine regulations regarding the

\footnotetext{
${ }^{32}$ Wellington, Antiquarianism and the Visual Histories of Louis XIV, 41.

${ }^{33}$ Ibid., $39-77$.

${ }^{34}$ Jacob Soll, "Jean Baptiste-Colbert's Republic of Letters," Republics of Letters: A Journal for the Study of Knowledge, Politics, and the Arts 1/1 (2009), at https://arcade.stanford.edu/sites/default/files/article_pdfs/ roflv01i01_Soll_071609_0.pdf.

${ }^{35}$ Dan Edelstein, The Enlightenment: A Genealogy (Chicago, 2010), 82. For a discussion of the Crown's role in eighteenth-century France, see Darrin M. McMahon, "Illuminating the Enlightenment: Public Lighting Practices in the Enlightenment," Past and Present 240/1 (2018), 119-59, esp. 139-40.

${ }^{36}$ Shank, Before Voltaire, 77-8. For more on Bignon's role see Jack A. Clarke, "Abbé Jean-Paul Bignon: 'Moderator of the Academies' and Royal Librarian," French Historical Studies 8/2 (1973), 213-35; Françoise Bléchet, "Le role de l'abbé Bignon dans l'activité des sociétés savantes aux XVIIIe siècle," in Actes du 100e congrès national des societés savantes (Paris, 1979), 31-41.
} 
election of its members, the schedule of meetings, and the expectations for individual research projects. The academy's membership was expanded to forty and divided into four different classes: honorary members, pensionary members supported by the Crown, associate members, and students, who were attached to one of the pensionaries.

The academy's early members included a broad range of prominent figures such as poets Jean Racine and Nicolas Boileau, the Benedictine historian Jean Mabillon, and the classical philologist André Dacier, among others. Despite differences in social standing and profession, the members were united by their curiosity about ancient history and their commitment to the erudite philological practices that had developed as a defining feature of humanist scholarship since the Renaissance. ${ }^{37}$ The forty members met every Tuesday and Friday (as they still do) to present their work in closed sessions at the Louvre. Twice a year they opened their sessions to the public. Procedures became increasingly regularized, and the academicians began to keep detailed minutes of their meetings starting in 1694 . These included attendance records and transcripts of presented papers. After new rules were outlined for the academy in 1701, the members were expected to work on various collaborative projects. Each academician was also supposed to choose some specific object of study and report on it during the meetings.

After the end of the War of the Spanish Succession in 1714, the academy could accept foreign scholars as corresponding members. The initial inductees included Cardinal Filippo Antonio Gualterio, the papal nuncio to France; the Benedictine numismatist Anselmo Banduri, who served as the librarian of Philippe II, duc d'Orléans (regent to King Louis XV); and Gisbert Cuper, a Dutch philologist and antiquarian who had been elected the mayor of Deventer. The foreign members maintained an active correspondence with their French counterparts, sending questions and reports about the curiosities they came across. These additions boosted the academy's international standing in the Republic of Letters, allowing its scholarship to circulate all over Europe while providing information about the findings of new artifacts and texts. ${ }^{38}$

Following Louis XIV's death in 1715, the academy was renamed the Académie royale des inscriptions et belles-lettres. It continued to advance the monarchy's image, but its members also undertook increasingly independent historical research. Voltaire's own account of these changes in the academy's structure in Le siècle de Louis XIV (1751) is enlightening:

The Academy of the Belles Lettres, initially comprised in 1663 of a few members of the French Academy in order to convey the actions of Louis XIV to posterity through the minting of medals, became useful to the public when it ceased to focus exclusively on the monarch and dedicated itself to research

\footnotetext{
${ }^{37}$ Donald R. Kelley, Foundations of Modern Historical Scholarship: Language, Law, and History in the French Renaissance (New York, 1970); George Huppert, The Idea of Perfect History: Historical Erudition and Historical Philosophy in Renaissance France (Urbana, 1970); Grafton, What Was History?, 62-122; James Turner, Philology: The Forgotten Origins of the Modern Humanities (Princeton, 2014), 33-64.

${ }^{38}$ For important studies of the Republic of Letters see Anne Goldgar, Impolite Learning: Conduct and Community in the Republic of Letters (New Haven, 1995); Dena Goodman, The Republic of Letters: The Cultural History of the French Enlightenment (Ithaca, 1996); Hans Bots and Françoise Waquet, La République des lettres (Paris, 1997).
} 
about antiquity and to a judicious critique of opinions and facts. It did more or less in the field of history what the Academy of Sciences did in physics: it dispelled errors. ${ }^{39}$

Voltaire would be one of many beneficiaries of the academicians' reexaminations of the past, although he questioned the relevance and applicability of ancient history. ${ }^{40}$

The Académie des inscriptions thus went from serving as a propaganda tool for promoting Louis XIV's absolutist regime to becoming the first modern historical research institute and an important part of the enlightened public sphere. While seventeenth-century scholars had also engaged in studies of past cultures and religions, the Académie provided a blueprint for how humanism could come under the purview of the state. Its members were fully devoted to engaging in historical research, presenting their work to peers, sharing their findings with the public, and judging essay contests. It would also serve as a model for similar institutions around Europe.

In 1717, the academy began to publish a periodical journal, the Mémoires de littérature tirez des registres de l'Académie des inscriptions, that made the scholarship of its members accessible to readers all over Europe. In his Letters Concerning the English Nation (1733), Voltaire mocked the "Collection of Transactions that abound with curious Researches and Critiques" for treating arcane subjects, but he admitted that the "Transactions are already esteem'd by Foreigners." ${ }^{41}$ Among these foreigners was the young Gibbon, who recalled "the joy with which I exchanged a bank-note of twenty pounds for the twenty volumes of the Memoires of the Academy of Inscriptions." The English historian described this journal as a "large and lasting fund of rational amusement" and credited it with feeding his own interests in ancient history and literature. ${ }^{42}$

Although the academicians' work was sponsored by the Crown, their research sometimes served to undermine the established order. Over the course of the eighteenth century, the Académie des inscriptions would become an important source of subversive ideas and one of the major "sites of antiabsolutism." ${ }^{43}$ Close examinations of past societies led scholars to intentionally and unintentionally unsettle the political and religious fabric of the Old Regime. Antiquarian erudition provided alternative ways-political, religious, and cultural-of conceptualizing the world. Encounters with previously little-known civilizations and new examinations of familiar sources allowed Enlightenment thinkers to formulate original understandings of the past. These new perspectives, in turn, shaped their reflections on the age in which they lived and informed their prognostications of humanity's future.

\section{Historical studies of culture}

Such dramatic changes occurred gradually, however, growing out of erudite examinations of past cultures. In the first volume of their serial publication, the

\footnotetext{
${ }^{39}$ Voltaire, Siècle de Louis XIV, ed. Diego Venturino, in Les oeuvres complètes de Voltaire, 13D: 4.

${ }^{40}$ For this interpretation see Force, "Voltaire and the Necessity of Modern History," 466-7.

${ }^{41}$ Voltaire, Letters Concerning the English Nation (London, 1733), 240.

${ }^{42}$ Edward Gibbon, Memoirs of the Life and Writings of Edward Gibbon, Esq., Composed by Himself, and Illustrated by and from His Letters and Journal, 2 vols. (London, 1830), 1: 102.

${ }^{43}$ Soll, The Information Master, 165.
} 
academicians explained why the institution was being renamed from the Académie royale des inscriptions et medailles to the Académie royale des inscriptions et belles-lettres. Their work, they noted, had long been concerned not only with the "deciphering of ancient medals and inscriptions or making new ones," but also had "encompassed almost all forms of erudition" including that which was "most obscure or most singular" in ancient and modern history. They sought to investigate ancient chronology and to uncover "the most instructive and the most useful" information provided by sources and "monuments ... from different centuries and different countries." 44 The publications were supposed to include general information related to "the origin of sciences among diverse peoples, to the cults of their divinities, to the details of their games and practices, to the knowledge of their laws and their systems [of thought]." ${ }^{\prime 5}$ The academicians developed their broad approach to the historical study of cultures by using the tools of humanist erudition and antiquarianism to reveal, dissect, and reconstruct the sheer complexity of past societies. The historians at the Academy of Inscriptions saw a clear relationship between religious beliefs, popular practices, and customs, on the one hand, and forms of political, social, and economic organization, on the other.

One could organize the articles of the Mémoires into several broad categories. The journal's coverage ranged from discussions of individual poets, philosophers, and historians to explorations of ancient myths and cults, to accounts of comparative chronologies, to studies of inscriptions and monuments, and, finally, to pieces about dance, athletics, and daily life. Among the tables of contents, one finds subjects as diverse as an account of nudity in the Greek Olympic games, a history of celibacy, an examination of the origins of the French nobility, an attempt to date the birth of Jesus Christ through numismatic evidence, the history of poor relief, and accounts of chronology in ancient China. The geographical scope of the academy's research expanded over the course of the eighteenth century to cover ever greater portions of the globe, especially as the academicians began to learn Mandarin, Sanskrit, and other extra-European languages. The inclusion of Asia, Africa, and the Americas was one of the key features in the transition from the biblically centered universal history to a truly global history. ${ }^{46}$

Many articles revealed an awareness of significant methodological differences between previous examinations of ancient and medieval cultures and the approach that the academicians were taking. For example, in his analysis of ancient oaths the abbé Guillaume Massieu noted that while a number of authors had previously written about the subject, "they treated it solely on the basis of legal or moral principles," while he was hoping to examine it with respect to "belles lettres." ${ }^{\text {" Th }}$ This meant analyzing the origin of oaths from their earliest appearance in human history, unearthing the divinities by which the ancients swore these oaths, studying

\footnotetext{
44"Preface," in Histoire de l'Académie royale des inscriptions et belles lettres, depuis son establissement jusqu'à present. Avec des Mémoires de littérature tirez des registres de cette Académie depuis son renouvellement jusqu'en MDCCX 1 (1717), [i-viii, at ii-iii].

${ }^{45}$ Ibid., [iii].

${ }^{46}$ Statman, "The First Global Turn," 369-71. See also Cécile Leung, Etienne Fourmont, 1683-1745: Oriental and Chinese Languages in Eighteenth-Century France (Leuven, 2002).

${ }^{47}$ Guillaume Massieu, "Dissertation sur les serments des anciens," Mémoires de littérature tirez des registres de l'Académie des inscriptions 1 (1717), 191-211, at 191.
} 
the different ceremonies that accompanied them, and examining the "role they played in civil society," among other questions. ${ }^{48}$ Massieu tried to make sense of how these particular practices functioned within their respective cultures. His article explained how the swearing of oaths established trust and promoted bonds of cohesion in different societies of antiquity.

Similarly, Antoine Banier tried to make sense of the variety of ancient myths in Egypt, the Near East, Greece, and Rome. He disputed the notion that these myths had a single source, as some historians had assumed, but argued, instead, that they were "the fruit of the human mind that was always drawn to the miraculous." 49 At the same time, Banier insisted that if one examined myths carefully and in the context of the "different times and countries in which one first saw them emerge," one would be able to discern "some utility" that they had. ${ }^{50}$ The various stories could be interpreted allegorically, and they offered explanations of the "great mysteries," such as the creation of the world and the generation of plants, to people who did not possess a solid grasp on natural philosophy. In other cases, the allegorical accounts contained faint traces of historical facts about the founding of particular cities or states. ${ }^{51}$

Banier's approach to pagan religions reflected a broader mythographical movement known as euhemerism, named after the ancient Greek thinker Euhemerus. Those who subscribed to this view (including Giambattista Vico, Bernard de Fontenelle, and Isaac Newton) believed that ancient myths were actually exaggerated accounts of real historical events. ${ }^{52}$ The gods and heroes of Egyptian and Greek mythology were based on regular human beings who were wise lawgivers, able military leaders, or people who invented various arts and sciences. It was thus "useful and in some sense necessary to know mythology," Banier noted in his larger treatise La mythologie et fables expliquées par l'histoire (1738), because they have "a real connection with the history of the first centuries," describing "considerable events" from that period. ${ }^{53}$ Banier and his colleagues at the Academy of Inscriptions tried to reexamine myths in ways that allowed them to find the underlying historical events. Eighteenth-century mythography thus became a historical science, one that sought to comb through myriad ancient accounts in the hope of "separating truth from nonsense, fiction from fact, superstition from actual occurrence," while shedding light on the nature of the civilizations that had produced them. ${ }^{54}$

\footnotetext{
${ }^{48}$ Ibid., 191-2.

${ }^{49}$ Antoine Banier, "Reflexions sur la mythologie," Histoire de l'Académie royale des inscriptions 12 (1740), 9-19, at 14 .

${ }^{50}$ Ibid.

${ }^{51}$ Ibid., 15.

${ }^{52}$ For more on euhemerism see Frank E. Manuel, The Eighteenth Century Confronts the Gods (Cambridge, MA, 1959); Nickolas P. Roubekas, An Ancient Theory of Religion: Euhemerism from Antiquity to the Present (New York, 2016); Laura Nicolì, "Uomini, dèi, santi: La natura umana della divinità nell'evemerismo settecentesco," in Carlo Borghero and Claudio Buccolini, eds., La Ragione e le sue vie: Saperi e procedure di prova in età moderna (Florence, 2015), 303-31.

${ }^{53}$ Antoine Banier, La mythologie et fables expliquées par l'histoire (Paris, 1738), ii.

${ }^{54}$ Manuel, The Eighteenth Century Confronts the Gods, 105.
} 
The tradition of ars historica, detailed by Anthony Grafton in his account of scholars such as Jean Le Clerc and Jacob Perizonius, continued to offer essential philological tools for analyzing and interpreting ancient sources. However, the academicians and their contemporaries began to approach these texts less as repositories of moral and political lessons for guiding behavior in the present and more as windows into cultures that were fundamentally different and that needed to be understood on their own terms. ${ }^{55}$ Texts from antiquity needed to be supplemented with material evidence and analyzed with reference to theories about the origins and functions of pagan religions. Such contextual reconsiderations offered more nuanced representations of the past, while helping to deal with the relative scarcity of textual evidence from the earliest periods of human history.

The academicians thus sought new ways to overcome the paucity and limitations of ancient sources, which often relied on oral traditions, myths, and legends. They thought that it was possible to interpret such information in new ways and to make sense of ancient myths and rituals in their specific cultural contexts. Examinations of the contents of past beliefs and rituals could reveal genuine insights into the attitudes of the peoples who had embraced them, thus providing a more complete understanding of their moeurs. In Force's analysis, Voltaire had distinguished between ancient and modern history, insisting that investigations into moeurs or the history of culture could only be fruitfully undertaken with respect to more recent history, while the study of antiquity was confined to the gathering of arcane facts: "as one went further into the past, things became less relevant and interesting." ${ }^{\text {" }}$ Voltaire would have thus been surprised to find that the members of the Académie des inscriptions were writing cultural histories of antiquity.

\section{The origins of ancient religions and cults}

Eighteenth-century scholars were increasingly interested in making sense of the startling variety of religions they encountered in historical writings and travel accounts. ${ }^{57}$ Books such as Jean Frederic Bernard's and Bernard Picart's Cérémonies et coutumes religieuses de tous les peuples du monde (1723-43) provided descriptions of diverse theologies and offered illustrations of how people around the globe practiced their beliefs. ${ }^{58}$ Comparative analyses of religions allowed for the exploration of both the diversity and the structural similarity of past and present

\footnotetext{
${ }^{55}$ Grafton, What Was History?, 252-4. For more on Perizonius see Frederic Clark, "Universal History and the Origin Narrative of European Modernity: The Leiden Lectures of Jacob Perizonius (1651-1715) on Historia Universalis," Erudition and the Republic of Letters 2 (2017), 359-95.

${ }^{56}$ Force, "Voltaire and the Necessity of Modern History," 466-7, quotation at 466; Force, "The 'Exasperating Predecessor'," 141.

${ }^{57}$ For more on eighteenth-centuries studies of religion see Manuel, The Eighteenth Century Confronts the Gods; Guy G. Stroumsa, A New Science: The Discovery of Religion in the Age of Reason (Cambridge, MA, 2010); Dmitri Levitin, "From Sacred History to the History of Religion: Paganism, Judaism, and Christianity in European Historiography from Reformation to 'Enlightenment'," Historical Journal 55/4, (2012), 1117-60; Anthony Ossa-Richardson, The Devil's Tabernacle: The Pagan Oracles in Early Modern Thought (Princeton, 2013).

${ }^{58}$ For more on this text see Lynn Hunt, Margaret C. Jacob, and Wijnand Mijnhardt, The Book That Changed Europe: Picart \& Bernard's Religious Ceremonies of the World (Cambridge, MA, 2010).
} 
beliefs. Religion appeared as the central unifying factor of human culture, and it offered a key to understanding other times and places.

Although some of the first academicians, such as Jean Mabillon, were notable historians of the Church, much of the eighteenth-century research at the Académie des inscriptions focused on pagan religions. The Académie's studies of ancient cults and religions, which significantly outnumbered their research into the history of Christianity and Church history, offer insight into how eighteenthcentury scholars, most of whom were still devout Christians, tried to make sense of alien systems of belief. In many cases, the academicians adopted what might be called proto-sociological explanations for what they saw as superstitious and erroneous beliefs of the ancients. Many tried to offer psychological accounts of superstition, citing, above all, a combination of fear and ignorance in the face of natural disasters and calamities. Nevertheless, the academicians often tried to see things from the perspective of their historical subjects. They sincerely attempted to describe what people in the past believed and to explain the possible reasons for those beliefs.

Although the vast majority of the academicians were not deists or atheists, their studies of past religions proved to be subversive to Christian dogma. They exposed difficulties about the age of the Earth and of humanity, which was problematic for Judeo-Christian chronology; they showed how religious leaders acted as impostors to fabricate miracles and manipulate popular superstitions; and they revealed uncanny similarities between Christianity and other mythological systems. The cumulative effect of the academy's erudite studies was thus inevitably corrosive to religious orthodoxy, and it is crucial to explaining the central paradox about the subversive nature of state-sponsored scholarship.

One of the more important questions touched on the origins of the various religions encountered in antiquity. The academicians and their counterparts debated whether human beings were initially monotheists or polytheists. Generally, the notion of a primitive monotheism that had been revealed to Adam was the more orthodox and theologically acceptable alternative. The abbé Nicolas-Hubert Mongault maintained, with many of his contemporaries, that the original belief in a single God became corrupted and turned into idolatry among the Assyrians, the Persians, and the Egyptians. Having forgotten the "true ideas of religion ... their mind, instead of lifting itself up to the supreme being and the cause of all good things, stopped at inferior and sensible causes." Physical bodies such as the sun, he argued, "became the object of their cult that was regulated by their different" natural and social needs. ${ }^{59}$

The academicians sought to explain the origin of cults and superstitions in ancient societies. They usually resorted to psychological or functionalist accounts. In his article on the cult of the god Bonus Eventus, Philibert-Bernard Moreau de Mautour attributed the origins of cults to "self-interest, self-love, and other passions and vices." $\mathrm{He}$ compared "the religious and healthy fear that, in a soul

\footnotetext{
${ }^{59}$ Nicolas-Hubert Mongault, "Dissertation sur les honneurs divins qui ont esté rendus aux gouverneurs des provinces pendant que la République Romaine subsistoit," Mémoires de littérature tirez des registres de l'Académie des inscriptions 1 (1717), 353-69, at 360.

${ }^{60}$ Philibert-Bernard Moreau de Mautour, "Dissertation sur le dieu Bonus Eventus et sur les médailles qui concernent son culte," Mémoires de littérature tirez des registres de l'Académie des inscriptions 2 (1717), $448-74$, at 448 .
} 
enlightened by the lights of faith, is the principle of wisdom" with a primal, unenlightened fear that "troubles human beings ... and that was the main source of the superstition of the pagans." ${ }^{161}$ The academicians thus popularized the idea that religious cults were informed by the ignorance of nature's laws and motivated by basic psychological needs.

The notion that primal fear was the main motivating factor in the establishment of ancient systems of belief became a widely shared assumption among the academicians. In his article on the representations of the gods Fear and Pallor on Roman medals, Moreau de Mautour argued that the destructive powers of nature caused people to become idolatrous and "to seek protectors who would save them from perils that menaced them." They became accustomed "to fear a hidden and secret power" that caused fortunes and misfortunes in their lives, and over time they established formal cults. ${ }^{62}$

Abbé Claude François Fraguier's article on curses that fathers placed on their children connected notions of paternal authority with the origins of cults. He argued that there was nothing more natural for those who felt oppressed and weak than to call upon the help of "a superior power" for protection or "vengeance for the evils that they had suffered at the hands of others." 63 He suggested that in order to discover the origins of cults and religions, one had to look back to a time before the establishment of states and political institutions. In these early societies, the children's "duty to their fathers extended" quite far and became a "formal aspect of religion." Those who dared to violate this duty would incur the "anger and vengeance of the gods." 64 Over time, Fraguier argued, inner feelings of remorse, shame, and guilt became externalized, transforming into divinities (the Furies) who would punish transgressors. ${ }^{65}$

The idea that the pagan gods were fashioned through attempts to externalize guilt and shame had many supporters at the Académie des inscriptions. Étienne Lauréault de Foncemagne's essay on the goddess Laverna highlighted the anthropomorphic nature of the Greek and Roman gods, observing that people tried to justify their "most shameful weaknesses by recognizing as the object of [their] cult divinities as weak as them and susceptible to the same passions [as them]." ${ }^{36}$ Even theft, which was a crime "that most directly attacked civil society," was "consecrated in the person of Mercury," as "the son of Jupiter was chosen as the patron of thieves." ${ }^{67}$ In his dissertation on the Fates (parques), the abbé Antoine Banier similarly argued that the true origin of these divinities was to be found in human selflove and desire to shun blame and responsibility for improper actions. It was precisely to "avoid the remorse of a criminal conscience," he argued, that people

\footnotetext{
${ }^{61}$ Ibid.

${ }^{62}$ Philibert-Bernard Moreau de Mautour, "De la Peur et de la Pâleur, divinitez representées sur les médailles Romaines," Histoire de l'Académie royale des inscriptions 9 (1736), 9-15, at 11-12.

${ }^{63}$ Claude François Fraguier, "Sur les imprécations des peres contre leurs enfans," Histoire de l'Académie royale des inscriptions 5 (1729), 23-31, at 23.

${ }^{64}$ Ibid., 24-5.

${ }^{65}$ Ibid., 26-7.

${ }^{66}$ Étienne Lauréault de Foncemagne, "De la déese Laverne," Mémoires de littérature tirez des registres de l'Académie des inscriptions 5 (1729), 50-62, at 50-51.

${ }^{67}$ Ibid., 51.
} 
"invented Gods that drove us to crimes by a fatal necessity." ${ }^{68}$ As a result, ancient tragedies always blamed the gods for the misfortunes that human beings seemingly brought upon themselves. Banier's essay on the Furies likewise insisted that paganism was originally conceived as a way to indulge human passions, thereby justifying the weakness of human nature. Consequently, the gods of the ancient pagans resembled human beings in their decadent behaviors, and religion provided a kind of excuse for unvirtuous acts. ${ }^{69}$

At the same time, Banier agreed with his fellow academicians that pagan religions contained mechanisms for regulating behaviors. Well before the Christians, the ancients came up with notions of the afterlife in which crimes and transgressions would be punished, while virtues would be rewarded. ${ }^{70}$ Even in periods of great ignorance when "the depravity of the heart cast shadows over the mind," he noted, people could still understand that "virtue is not always recompensed in this world nor are crimes [always] punished." Consequently, they came up with the notion that there had to be a place "to punish the evil and reward the good," and that is how they came up with the idea of the Elysian Fields. ${ }^{71}$

These accounts tried to demonstrate how corrupted understandings that lost sight of original monotheistic ideas tried to make sense of the world around them. Although primitive monotheism was widely supported, the academicians' accounts of ancient religions focused almost exclusively on paganism. They explained how the ancients worshipped their gods and shed light on the psychological origins of various superstitions. Such an approach signaled a subtle shift away from the humanist pursuit of prisca sapientia, of pristine theological and philosophical knowledge that supposedly had been available to the ancients. Rather than looking at how the purportedly original and true religion was perverted by pagan beliefs, the academicians attempted to examine ancient paganism on its own terms, treating antiquity as a foreign culture worthy of exploration for its own sake.

Not all embraced the theory of primitive monotheism, however. Charles de Brosses, who invented the term "fetishism," claimed that the ancient Egyptian religion was always based on the practice of animal worship. He rejected the notion that this practice contained any underlying figurative or mystical meanings, as earlier scholars like Athanasius Kircher had claimed. Comparing Egyptian ceremonies to religious practices in contemporary Guinea (about which he read in travel accounts), de Brosses insisted that all religions of early human societies involved similar structural elements of what he called "brute-worship." So-called primitive human beings reasoned in the manner of children and were missing the spark of true religion. De Brosses argued that they worshiped animals and objects because they were unable to formulate abstract notions of the divinity, suggesting, as David Hume had three years earlier, that the first societies were not monotheistic,

\footnotetext{
${ }^{68}$ Antoine Banier, "Dissertation sur les Parques," Mémoires de littérature tirez des registres de l'Académie des inscriptions 5 (1729), 14-33, at 20.

${ }^{69}$ Antoine Banier, "Dissertation sur les Furies," Mémoires de littérature tirez des registres de l'Académie des inscriptions 5 (1729), 34-50, at 34.

${ }^{70}$ Ibid., 34-5.

${ }^{71}$ Ibid., 37-8.
} 
but polytheistic and idolatrous. ${ }^{72}$ Such views challenged the orthodox Christian concept of an original Adamic religion, and they would be taken up by atheist thinkers, such as the baron d'Holbach and Nicolas-Antoine Boulanger. ${ }^{73}$

Boulanger's work in particular revealed strong debts to the Académie's research. His L'antiquité dévoilée par ses usages (1766) cited the Mémoires of the Académie des inscriptions in numerous places, and his analysis of the psychological origins of pagan religions strongly resembled the reasoning of academicians such as Banier, de Brosses, Fraguier, and Moreau de Mautour. Like his earlier Recherches sur l'origine du despotisme oriental (1761), Boulanger's L'antiquité dévoilée traced the origins of ancient religions to how early societies responded to natural disasters, such as floods and fires. References to these events and to the universal Flood appeared in the histories of all ancient peoples, testifying to the high likelihood that the deluge was in fact universal. Following the Flood, Boulanger hypothesized, human nature became fundamentally transformed. Traumatized by such calamities and subject to the whims of nature, the earth's inhabitants lived in a state of constant fear. They reconstituted societies anew, inventing religious ceremonies and rituals that, according to their feeble understanding of the laws of nature, would pacify deities who they thought controlled natural phenomena. ${ }^{74}$ Thus, Boulanger attributed the origins of ancient religious and political institutions to the traumatic experiences of the universal deluge. Like his counterparts at the Académie des inscriptions, he saw myths and fables as important sources for uncovering the historical foundations of human societies. ${ }^{75}$

\section{Functionalist explanations of religious practices}

In seeking to make sense of ancient religions and cults, the academicians often adopted functionalist explanations of the role that people's beliefs and practices played in the maintenance of the social order. Rather than highlighting the ignorance and superstition of those who believed in the pagan divinities, the scholars at the Académie examined how different religious rituals worked to promote human association. They also highlighted the ways in which these practices helped to establish laws and contribute to the functioning and progress of ancient societies.

While the academicians were frequently critical of ancient superstitions, they also perceived the social and political utility of pagan religions. For example, in

\footnotetext{
${ }^{72}$ Charles de Brosses, Du culte des dieux fétiches, ou Parallèle de l'ancienne religion de l'Egypte avec la religion actuelle de Nigritie (1760). For more on de Brosses's notion of fetishism see Rosalind C. Morris and Daniel H. Leonard, eds., The Returns of Fetishism: Charles de Brosses and the Afterlives of an Idea (Chicago, 2017). For more on Hume's and de Brosses's views see Michel Malherbe, "Hume's Reception in France," in Peter Jones, ed., Receptions of David Hume in Europe (London, 2005), 43-97, esp. 64-70; and Renée Koch Piettre, "President de Brosses's Modern and Post-modern Fetishes in the Historiography and History of Religions," in Bernd-Christian Otto, Susanne Rau, and Jörg Rüpke, eds., History and Religion: Narrating a Religious Past (Berlin, 2015), 393-405. For Hume's connections to the Academy of Inscriptions see Pedro Faria, "David Hume, the Académie des inscriptions, and the Nature of Historical Evidence in the Early Eighteenth Century," Modern Intellectual History (2020), https://doi. org/10.1017/S1479244319000404.

${ }^{73}$ Alan Charles Kors, D'Holbach's Coterie: An Enlightenment in Paris (Princeton, 1976); Philipp Blom, A Wicked Company: The Forgotten Radicalism of the European Enlightenment (New York, 2010).

${ }^{74}$ Nicolas-Antoine Boulanger, L'antiquité dévoilée par ses usages, 3 vols. (Amsterdam, 1766), 1: 10-16.

${ }^{75}$ Ibid., 29-32.
} 
explaining the origins of the cult of the god Terminus, Claude Gros de Boze, the perpetual secretary of the Académie from 1706 to 1742, examined how Roman king Numa Pompilius tried to curb popular passions. Seeking to curtail the human drive to expand one's domination over others, which inevitably led to violent wars, Numa established this cult of Terminus, the god of boundaries. According to Gros de Boze, Numa revived an ancient law but "added new penalties" and, to make it "more sacred and inviolable, he persuaded people that there was a particular god" who served as "the protector of borders and the avenger of usurpations." The Roman legislator thus found it necessary "to involve religion in politics" in order to "restrain by the fear of the Gods" those who were not controlled by established laws. ${ }^{76}$ Like Niccolò Machiavelli's examination of the practical effects of the Roman religion in the Discourses on Livy (1531), Gros de Boze's analysis drew on Livy but also relied on other historians, including Polybius, Plutarch, Suetonius, and Dionysius of Halicarnassus. After exploring Numa's attempts to use the fear of the gods to pacify unruly Romans, the article explained how different kings, consuls, and emperors made use of the cult of Terminus.

In a similar fashion, Moreau de Mautor, who wrote on the gods Fear and Pallor, described how the deification of fear, which he saw as the origin of religious superstition, played a role in the political and judicial systems of ancient states. He argued that leaders attempted to harness human anxieties in order to establish and maintain political control. He mentioned several examples, including the Spartans, who erected the temple of Fear near the tribunal of the ephors, and the Corinthians, who made regular sacrifices to the statue of Fear. ${ }^{77}$ The academicians thus saw pagan cults as playing a key role in the institution of laws and in the maintenance of the social order.

Pagan religions could also serve to establish and preserve bonds of cohesion among rival groups and tribes. In his account of Roman religious ceremonies, the abbé Jean-Baptiste Couture suggested that in seeking political stability, the Senate and the consuls inculcated fear and obligation in the people. They appointed a dictator who would "implore the assistance of heaven" and would be endowed with supernatural authority in the minds of the people. ${ }^{78}$ Similarly, he argued that Tarquin the Proud, the last king of Rome, tried to form a confederation among the neighboring tribes and cement it with "the seal of religion" and communal celebrations. ${ }^{79}$

Nicolas Fréret, who followed Gros de Boze as the academy's perpetual secretary from 1742 to 1749 and whose name was used on several clandestine deist manuscripts in the second half of the eighteenth century, likewise explained how ancient politicians exploited common credulity. ${ }^{80}$ In his article on ancient miracles he

\footnotetext{
${ }^{76}$ Claude Gros de Boze, "Du dieu Terme et se son culte chez le Romains," Mémoires de littérature tirez des registres de l'Académie des inscriptions 1 (1717), 50-58, at 50-51.

${ }^{77}$ Moreau de Mautour, "De la Peur et de la Pâleur," 13.

${ }^{78}$ Jean-Baptiste Couture, "Des cérémonies de religion, pour lesquelles on a eu recours à la dictature, c'est à dire, du clou sacré, \& des féries Romaines," Mémoires de littérature tirez des registres de l'Académie des inscriptions 6 (1729), 190-207, at 190.

${ }^{79}$ Ibid., 201.

${ }^{80}$ For more on Fréret see Renée Simon, Nicolas Fréret, académicien (Geneva, 1961); Danielle Elisseeff, Nicolas Fréret (1688-1749): Réflexions d’un humaniste du XVIIIe siècle sur la Chine (Paris, 1978);
} 
distinguished between two kinds of supposedly supernatural events. The first category included occurrences that "could not be explained without recourse to a supernatural cause" and "without supposing that God" produced these occurrences to further deceive human beings, which would undermine the "miracles in favor of the true religion." Citing examples from Roman mythology, Fréret argued that "one should regard all such facts and all those that resemble them as fables invented by corrupt priests and believed by an ignorant and superstitious public." The second category of ancient miracles included "purely natural effects" that "occurred less frequently and, appearing contrary to the ordinary course of nature, were attributed to a supernatural cause by the superstition of men scared by the sight of unknown objects." He observed that this second category of seemingly supernatural events was frequently used by politicians to "inspire in people feelings that conformed with their designs" to make them believe that particular courses of action were divinely sanctioned. ${ }^{81}$ Such descriptions of the practical uses of belief would become an important theme in Jean-Jacques Rousseau's theory of civil religion in $\mathrm{Du}$ contrat social (1762). These approaches also reflected a more general trend, as Enlightenment thinkers increasingly considered religion from a more utilitarian rather than metaphysical perspective. ${ }^{82}$

The academicians thus explained how religious beliefs, cults, and superstitions played important roles in the functioning of ancient societies. While they explained such perspectives with reference to what might be described as psychological reductionism, their analyses seemed to accept the fact that these beliefs were real for those who had embraced them in so far as they helped to inform people's behaviors and practices. Their comparative studies of religions would form the foundations of the emerging field of comparative religious studies. Their scholarship also provided

Blandine Barret-Kriegel, Les historiens et la monarchie, vol. 1, Jean Mabillon (Paris, 1988), 161-210; Chantal Grell and Catherine Volpilhac-Auger, eds., Nicolas Fréret, légende et vérité: Colloque des 18 et 19 octobre 1991, Clermont-Ferrand (Oxford, 1994); Catherine Volpilhac-Auger, "Fréret, l'arpenteur universel," Corpus: Revue de philosophie 29 (1995), 7-18; Carlo Borghero, "Méthode historique et philosophique chez Fréret," Corpus: Revue de philosophie 29 (1995), 19-38; Claudine Poulouin, "Fréret et les origines de l'histoire universelle," Corpus: Revue de philosophie 29 (1995), 39-62; Nadine Vanwelkenhuyzen, "Langue des hommes, signes Dieux: Fréret et la mythologie,” Corpus: Revue de philosophie 29 (1995), 63-75.

${ }^{81}$ Nicolas Fréret, "Reflexions sur les prodigies rapportez dans les anciens," Mémoires de littérature tirez des registres de l'Académie des inscriptions 4 (1723), 411-12.

${ }^{82}$ For more on religion in the Enlightenment see Dale K. van Kley and James E. Bradley, eds., Religion and Politics in Enlightenment Europe (Notre Dame, 2001); S. J. Barnett, The Enlightenment and Religion: The Myths of Modernity (Manchester, 2003); David Sorkin, The Religious Enlightenment: Protestants, Jews, and Catholics from London to Vienna (Princeton, 2008); Jeffrey D. Burson, The Rise and Fall of Theological Enlightenment: Jean-Martin de Prades and Ideological Polarization in Eighteenth-Century France (Notre Dame, 2010); William J. Bulman, Anglican Enlightenment: Orientalism, Religion and Politics in England and Its Empire, 1648-1715 (Cambridge, 2015); William J. Bulman, "Introduction: Enlightenment for the Culture Wars," in William J. Bulman and Robert G. Ingram, eds., God in the Enlightenment (Oxford, 2016), 1-41; Anton M. Matytsin, "Reason and Utility in French Religious Apologetics," in Bulman and Ingram, God in the Enlightenment, 63-82; Anton M. Matytsin and Dan Edelstein, "Introduction," in Anton M. Matytsin and Dan Edelstein, eds., Let There Be Enlightenment: The Religious and Mystical Sources of Rationality (Baltimore, 2018), 1-31; Jeffrey D. Burson, The Culture of Enlightening: Abbé Claude Yvon and the Entangled Emergence of the Enlightenment (Notre Dame, 2019); Ashley Walsh, Civil Religion and the Enlightenment in England, 1707-1800 (Woodbridge, 2020). 
new perspectives from which Enlightenment thinkers could critically examine their own faiths.

The contours of how many of the Académie's members studied ancient religions indeed would inform how deist and atheist critics approached the study of Christianity. Baruch Spinoza's Tractatus Theologico-Politicus (1670), the Traité sur les trois imposteurs, or Jean Méslier's Testament (1729), among other clandestine texts, directly challenged the divine origins of Christianity and pointed to the unholy alliance between religious and political authorities that had conspired to usurp power over the ignorant masses. ${ }^{83}$ Eighteenth-century readers did not need to access these clandestine atheist texts, however, to arrive at the notion that common superstitions could be easily exploited for the sake of political control. Accounts of the way that ancient religious and political authorities made use of popular beliefs were readily available on the pages of the Académie's Mémoires. The academicians' erudite studies provided ample evidence that had dramatic implications for how Enlightenment thinkers would look at all organized religions, especially Christianity.

\section{The study of daily life}

The Académie's studies of past societies also involved examinations of rituals and daily practices. Such information provided key insights into how ancient societies functioned as complex units and how their customs shaped forms of legal and political organization. It also allowed scholars to engage in comparative historical analyses and seek the origins of modern states. ${ }^{84}$ For example, René Aubert de Vertot's article on the beginnings of the French nation analyzed the conformity between the customs of the various Germanic tribes and of the Gauls. He noted the similarity between the languages, the laws, the customs, the structure of public assemblies, the conduct of war, and the management of domestic affairs of the Germans and of the first French. Vertot highlighted the militaristic nature of these societies, which distinguished their leaders for bravery in combat, but he also observed the consultative nature of their political organization that required the consent of the whole people

\footnotetext{
${ }^{83}$ For more on this heterodox literature see Ira O. Wade, The Clandestine Organization and Diffusion of Philosophic Ideas in France from 1700 to 1750 (Princeton, 1938); C. J. Betts, Early Deism in France: From the So-Called "Deists" of Lyon (1564) to Voltaire's Lettres philosophiques (1734) (The Hague, 1984); Miguel Benitez, La face caché des Lumières: Recherches sur les manuscrits philosophiques clandestins de l'âge classique (Paris and Oxford, 1996); Antony McKenna and Alain Mothu, eds., La philosophie clandestine à l'âge classique (Paris and Oxford, 1997); Pascal Taranto, Du déisme à l'athéisme: La libre-pensée d'Anthony Collins (Paris, 2000); Jonathan I. Israel, Radical Enlightenment: Philosophy and the Making of Modernity 1650-1750 (Oxford, 2001); Gianni Paganini, Les philosophies clandestines à l'âge classique (Paris, 2005); Diego Lucci, Scripture and Deism: The Biblical Criticism of the Eighteenth-Century British Deists (New York, 2008); Stephen M. Nadler, A Book Forged in Hell: Spinoza's Scandalous Treatise and the Birth of the Secular Age (Princeton, 2011); Charles Devellennes, "Radical Atheism: Jean Meslier in Context," in Steffen Ducheyne, ed., Reassessing the Radical Enlightenment (London and New York, 2017), 160-77.

${ }^{84}$ For more on the emergence of medieval studies see Gossman, Medievalism and the Ideologies of the Enlightenment; Alicia C. Montoya, Sophie van Romburgh, and Wim van Anrooij, eds., Early Modern Medievalisms: The Interplay between Scholarly Reflection and Artistic Production (Leiden, 2010); Alicia C. Montoya, Medievalist Enlightenment from Charles Perrault to Jean-Jacques Rousseau (Woodbridge, 2013).
} 
in the making of important decisions. ${ }^{85}$ They placed great value on liberty and resisted foreign domination. He noted that the Roman conquest of the French transformed their customs, as they exchanged swords for plowshares and began to cultivate the land. ${ }^{86}$ However, he was ambivalent about the consequences of this transformation, noting that by following seemingly "savage and ferocious" customs, the "first French people conquered the greater part of Europe," while their descendants have "squandered" those conquests "through their luxury and idleness." Vertot's analysis suggested a complex interplay between the military success of societies and their level of refinement. He implied that the barbarous virtues of the ancient Gauls were not altogether negative, while the advancement of polite mores had its downsides. Critics of Enlightenment theories of progress, such as Rousseau and his acolytes, would later take up similar arguments.

The series of articles on the private life of the Romans by Jean-Baptiste Couture is another prime example of the way in which the academicians perceived the complex relationship between cultural practices and historical development. Couture noted a clear connection between the corruption of morals, visible in the daily life of the Romans, and changes in their political structure. Under the kings, he observed, "people lived in great mediocrity and, therefore, in great simplicity." 88 However, after they expelled the Tarquin monarchs, the Romans "had no other brake but reason, and since reason is very weak" at restraining human passions, the patricians and plebeians could not "moderate their desires" and became increasingly dissatisfied with one another. ${ }^{89}$ Couture traced the corruption of mores by looking at the changes in how the Romans spent different hours of the day. While earlier generations, driven by rustic ideals, had distinguished themselves by rising early and working hard on the land, the love of luxury gradually corrupted Roman citizens. Couture blamed the increasing greed and laziness on the Greeks, who perverted the Romans by bringing a penchant for extravagance and idleness to Italy. This general degeneration of mores was difficult to stop, and it trickled down from the patricians to the lower classes. Eventually, it led to the proliferation of slavery, which provided more time for various pleasantries and amusements. ${ }^{90}$

These discussions were not only of historical interest, but also had concrete political implications for France in the years after the death of Louis XIV. Debates about whether the French economy should follow the models set by the commercebased Dutch Republic and Great Britain or focus on the development of agriculture would feature prominently in a number of intellectual circles. ${ }^{91}$ Couture's account

\footnotetext{
${ }^{85}$ René Aubert de Vertot, "Dissertation dans laquelle on tâche de démesler la véritable origine des François par un paralelle de leurs moeurs avec celle des Germains," Mémoires de littérature tirez des registres de l'Académie des inscriptions 2 (1717), 611-50, at 612-14.

${ }^{86}$ Ibid., 621-2.

${ }^{87}$ Ibid., 647.

${ }^{88}$ Jean-Baptiste Couture, "De la vie privée des Romains. C'est-à-dire: Ce qu'un particulier, menant une vie commune, faisoit dans le cours d'une journée; les heures ajustées à nostre maniere de compter," Mémoires de littérature tirez des registres de l'Académie des inscriptions 1 (1717), 303-17, at 303-4.

${ }^{89}$ Ibid., 304.

${ }^{90}$ Ibid., 306-8.

${ }^{91}$ See, for example, Istvan Hont, "The Early Enlightenment Debate on Commerce and Luxury," in Mark Goldie and Robert Wokler, eds., The Cambridge History of Eighteenth-Century Political Thought (Cambridge, 2006), 379-418; Isaac Nakhimovsky, "The Enlightened Prince and the Future of Europe:
} 
of ancient Rome implicitly described the potential dangers that commerce and luxury could bring to otherwise virtuous societies. His praise for the rustic simplicity of the Romans resembled François Fénelon's portrayal of the fictional Baetica in Les aventures de Télémaque (1699) and foreshadowed the success of the Physiocrats, who placed primary importance on the productivity of agriculture.

These articles appeared well before Montesquieu published his Considérations sur les causes de la grandeur des Romains et de leur décadence in 1734. Montesquieu was quite close with several members of the Académie, and his analysis of Rome's decline echoed the findings of scholars like Couture. He too observed that the Romans had been corrupted by their riches. ${ }^{92}$ Montesquieu's examination of the causes of the ruin of the Roman Republic, as well as his later De l'esprit des lois (1748), drew on the contents and methods of historical analysis that had been developed over several decades by numerous members of the Academy of Inscriptions. Montesquieu and Voltaire learned from the academicians that a proper historical analysis of past societies required a nuanced understanding of the mosaic of cultural elements that gave coherent identities to those cultures. One could not properly analyze the causes of the rise and fall of empires without taking note of the various customs and motivations that shaped their inhabitants.

\section{Progress and decline}

Studies of the past led the academicians and their contemporaries to think about the age in which they lived and to become more self-reflexive about their own place in the process of historical evolution. By analyzing the parallel development of civilizations, they formulated new theories of human progress and philosophies of history. Their research helped to generate stadial theories of development that posited several distinct stages through which all civilizations passed. Versions of these theories would appear in the works of Enlightenment philosophers such as Adam Ferguson and Nicolas de Condorcet and nineteenth-century thinkers such as Auguste Comte and Karl Marx.

The academicians were especially interested in examining "the advancement of letters," which spread "general knowledge, taste, and discernment that contributed to a preeminence of nations," as the preface to the first volume of the Mémoires declared. $^{93}$ Many articles revealed progressive conceptions of history and of human reason that were becoming a characteristic trait of eighteenth-century learned culture. Dan Edelstein has argued that the emergence of this self-reflexive narrative was the defining feature of the Enlightenment. It was based on the recognition by eighteenth-century thinkers that they lived in an enlightened age, in which the progress of science combined with a new philosophical spirit to bring humankind to an unprecedented apex of intellectual and cultural achievement. ${ }^{94}$

\footnotetext{
Voltaire and Frederick the Great's Anti-Machiavel of 1740," in Béla Kapossy, Isaac Nakhimovsky, and Richard Whatmore, eds., Commerce and Peace in the Enlightenment (Cambridge, 2017), 44-77; Ryan Patrick Hanley, The Political Philosophy of Fénelon (Oxford, 2020), 49-82.

${ }^{92}$ Montesquieu, Considérations sur les causes de la grandeurs des Romains et de leur décadence (Amsterdam, 1734), 103-4. For a comparison between Montesquieu's and Gibbon's discussions of luxury see J. G. A. Pocock, Barbarism and Religion, vol. 3, The First Decline and Fall (Cambridge, 2005), 424-40.

93"Preface," Histoire de l'Académie royale des inscriptions 1 (1717), [vii].

${ }^{94}$ Edelstein, The Enlightenment, 1-2.
} 
While not all thinkers shared this view of progress, many of the Académie's members subscribed to aspects of it. In the first article of the inaugural volume of the Mémoires, the abbé Eusèbe Renaudot described the gradual improvement in the study of astronomy and chronology among the ancients and the moderns. He traced this history from what he called the "crude" and "ridiculous" opinions of the Egyptians, the Babylonians, and the Chaldeans, all of whom had maintained superstitious views about the role of the heavenly bodies in human affairs. ${ }^{95}$ Renaudot followed this progressive account to what he described as increasingly sophisticated understandings of astronomy among the medieval Jews and Arabs, to thinkers such as Roger Bacon, Nicolaus Copernicus, Tycho Brahe, and Galileo Galilei. ${ }^{96}$ For many academicians, progress in the sciences went hand in hand with progress of letters. Their accounts often resembled triumphalist histories of the rise of modern philosophy that appeared in the late seventeenth century and would feature prominently in the "Discours préliminaire" to the Encyclopédie and in so many of its articles that cited the Académie's Mémoires. ${ }^{97}$

The Académie was also caught up in the Quarrel of the Ancients and Modernsa late seventeenth-century debate about whether modern authors and artists surpassed the ancients in literary and artistic abilities-and its members often sided with the ancients. ${ }^{98}$ Many of them had become so fascinated by the cultural and intellectual achievements of antiquity that they did not share the moderns' unequivocal belief in the progress of the human mind. The enigmatic Nicolas Fréret, for example, concluded his article on ancient miracles by expressing reservations about the extent to which his century surpassed previous ages in learning. He speculated that "people have had more or less the same level of enlightenment in all ages," and urged his contemporaries to not "show contempt for the knowledge and reflections of those who preceded" them. ${ }^{99}$

\footnotetext{
${ }^{95}$ Eusèbe Renaudot, "De l'origine de la sphère," in Mémoires de littérature tirez des registres de l'Académie des inscriptions 1 (1717), 1-25, at 4.

${ }^{96}$ Ibid., 23-4.

${ }^{97}$ For notable examples of the Encyclopédie articles that makes explicit references to the Mémoires see "Bibliothèque" (vol. 2), "Célibat" by Denis Diderot (vol. 2), "Chronologie sacrée" by Diderot (vol. 3), "Courtisane" by Jean le Rond d'Alembert (vol. 4), "Critique" by Edme-François Mallet (vol. 4), "Déclamation des anciens" by Charles Pinot Duclos (vol. 4), "Déesses-meres", by Louis de Jaucourt (vol. 4), "Encyclopédie" by Diderot (vol. 5), "Érudition" by d'Alembert (vol. 5), "Équitation" by Charles-Louis d'Authville Des Amourettes (vol. 5), "Éternument" by Jaucourt (vol. 6), "Étymologie" by Anne-Robert-Jacques Turgot (vol. 6), "Évangile" by Mallet (vol. 6), "Exorcisme magique" by Mallet (vol. 6), "Fable" by Jaucourt (vol. 6), "Fastes" by Jaucourt (vol. 6), "Hyperboréens" by Jaucourt (vol. 8), "Hysterolite" by the baron d'Holbach (vol. 8), "Inde" by Jaucourt (vol. 8), "Langue" by Nicolas Beauzée (vol. 9), "Lydie" by Jaucourt (vol. 9), "Médaille antique" by Jaucourt (vol. 10), "Mythologie" by Jaucourt (vol. 10), "Nécromancie" by Mallet (vol. 11), "Olympe" by Jaucourt (vol. 11), "Parques" by Jaucourt (vol. 12), "Saliques" (vol. 14); “Théatre des anciens" by Jaucourt (vol. 16).

${ }^{98}$ For more on the querelle des anciens et des modernes see Joseph M. Levine, "Ancients and Moderns Reconsidered," Eighteenth-Century Studies 15/1 (1981), 72-89; Barret-Kriegel, La défaite de l'érudition, 269-306; Joan DeJean, Ancients against Moderns: Culture Wars and the Making of a Fin de Siècle (Chicago, 1997); Edelstein, The Enlightenment, 24-51; Larry F. Norman, The Shock of the Ancient: Literature and History in Early Modern France (Chicago, 2011); Paddy Bullard and Alexis Tadié, eds., Ancients and Moderns in Europe: Comparative Perspectives (Oxford, 2016).

${ }^{99}$ Fréret, "Reflexions sur les prodigies," 36.
} 
Some academicians also believed in the moral degeneration of the original human nature among the most ancient peoples that resembled biblical accounts of humanity's fall from grace. For example, Guillaume Massieu's treatise on oaths posited a golden age, during which human beings behaved with a view for "common utility" and without regard for personal interest. People began to make oaths and promises only after human nature was corrupted, and they sought to deceive, outwit, and destroy one another. ${ }^{100}$ Vertot, who wrote on the history of the early French and observed a general progress in letters since the middle ages, shared this view of ancient decline. He argued that "if men had conserved the customs and the innocence of the first age" they would not need to resort to using oaths. However, self-interest, ambition, and violent passions corrupted human nature, giving birth to infidelity and lying. ${ }^{101}$

These debates about the progress and degeneration of humanity would become central to later Enlightenment contestations. By the middle of the eighteenth century, we see a clear split between the progressive visions of Voltaire, d'Alembert, and Condorcet, the cyclical model posited by Montesquieu, and Rousseau's portrayal of humanity's moral decay. The Académie's members did not share a consensus on the matter, but their dissertations provided the content and themes for future debates, and they offered the general contours of the positions their heirs would take. This lack of consensus complicates the narrative according to which most Enlightenment thinkers held a decisively optimistic view of human progress. Historical examples provided by the academicians served to undermine overly simplistic and linear narratives that some philosophes proposed.

\section{Conclusion}

The Académie's studies of ancient and medieval cultures reflect the broad range of its members' interests and preoccupations. The academicians did not intend to undertake revolutionary revisions of the past. However, by seeking out new information and meticulously following the sources to unexpected places, they helped to upend the traditional narrative of Judeo-Christian universal history. Their research of other societies ultimately pushed them to reflect more critically on their own age and to begin to see themselves from the perspective of other cultures. The academicians' examinations of religious beliefs, daily practices, and moeurs constitute what might be called "cultural histories." These histories help us foreground new ways of thinking about the Enlightenment less in terms of a commitment to particular philosophical or theological perspectives and more in terms of a shared methodology in gathering information about the past and present state of human affairs.

While not intentionally subversive, the research of the academy's members revealed new epistemological approaches to historical scholarship. Facing a skeptical crisis of certainty in the early 1700s, the academicians helped to come up with new ways of ascertaining facts about the past and verifying the authenticity

\footnotetext{
${ }^{100}$ Massieu, "Dissertation sur les serments des anciens," 192.

${ }^{101}$ René Aubert de Verot, "Dissertation sur l'ancienne forme des serments usitez parmi les François," Mémoires de littérature tirez des registres de l'Académie des inscriptions 2 (1717), 700-27, at 700.
} 
of textual and material evidence. They distinguished that which could be known with a relative degree of certainty from that which was unknowable. ${ }^{102}$ Academicians like Fréret argued against imposing on history the standard that mathematics and metaphysics required, insisting that historical demonstrations could never reach complete metaphysical certainty and that history, as a human science, should have its own standards of proof. ${ }^{103}$ Their encounters with new sources and debates about methodology reshaped the historical discipline and helped to form the embryonic foundations of fields such as cultural anthropology, archaeology, and comparative religious studies. ${ }^{104}$

The academicians' explorations of past cultures also reveal important changes in the ways in which eighteenth-century scholars thought about the human subject and the role that culture played in shaping past and present societies. Their descriptions of how pagan customs served as checks on the passions sought to make sense of psychological factors that regulated human behavior. Like many of their contemporaries, the academicians recognized that people were more frequently driven by their passions and their fears than by reason. Their explanations of human motivation informed broader eighteenth-century concerns about how to regulate and harness individuals' basic drives and needs within a framework of complex societies. ${ }^{105}$ Their attempts to identify trends in the progress or decline of ancient empires also reveal complex understandings of the cultural, social, and economic dynamics that drove historical change.

The academicians conducted their work with the support of the French state and within the confines of a royal institution. Nevertheless, that institution served as a cradle and a springboard for many ideas that we tend to associate with the more radical aspects of eighteenth-century learned culture. A study of the Académie des inscriptions reminds us that the French Enlightenment was not confined to a small group of rebellious philosophes; it could be found not only in private salons and Parisian cafés but also in the halls of the Louvre, at the very center of royal power, where scholars served the interests of the state while engaging in innovative historical research. The Republic of Letters and the Enlightenment were involved in a complex dialectic between erudite freethinking and the increasing power of the state. Institutions such as the Académie des inscriptions could thus simultaneously support and undermine the authority of the Crown, depending on how their particular members chose to deploy the production and dissemination of knowledge.

The Académie's research also reveals surprising continuities between the erudite work of humanist antiquarians and what some might call revolutionary approaches of eighteenth-century philosophes. In attempting to emphasize their own

\footnotetext{
${ }^{102}$ For debates about historical skepticism see Anton M. Matytsin, "Historical Pyrrhonism and Historical Certainty in the Early Enlightenment," in Elodie Argaud, Nawalle El Yadari, Sébastien Charles, and Gianni Paganini, eds., Pour et contre le scepitcisme: Théories et pratiques de l'Antiquité aux Lumières (Paris, 2015), 243-59; Anton M. Matytsin, The Specter of Skepticism in the Age of Enlightenment (Baltimore, 2016), $233-63$.

${ }^{103}$ Nicolas Fréret, "Réflexions sur l'étude des anciennes histoires, et sur le dégré de certitude de leurs preuves," Mémoires de littérature tirez des registres de l'Académie des inscriptions 6 (1729), 146-89, at 184-5.

${ }^{104}$ For a detailed history of these disciplines see Turner, Philology, 123-229.

${ }^{105}$ For more about these discourses see David Wootton, Power, Pleasure, and Profit: Insatiable Appetites from Machiavelli to Madison (Cambridge, MA, 2018).
} 
originality, d'Alembert and Voltaire sometimes belittled erudite antiquarianism. They created a straw man by equating previous scholarship with the medieval chronicle tradition that lacked analysis. Describing erudition as a merely preparatory to philosophy, d'Alembert articulated a historical narrative according to which part of being enlightened meant transcending erudition. However, d'Alembert's and Voltaire's universal histories of the progress of the human mind were not produced ex nihilo; they also had their own history, and the philosophes were indebted to the work of numerous scholars who supplied them with new methodologies and raw materials out of which they could construct their triumphalist narratives. The academicians were no strangers to philosophical history or to analyzing the complex factors that contributed to the rise and decline of civilizations. However, for them, as for Gibbon, there was no sharp contrast between history and philosophy. A truly enlightened and philosophical understating of the past required textured and nuanced accounts of lived experiences, including daily life, religious practices, and social psychology. Enlightenment and erudition were meant to be pursued in tandem.

Acknowledgments. Versions of this paper were presented at the University of Southern CaliforniaHuntington Eighteenth-Century Studies Colloquium in 2017, the Triangle French History and Culture Seminar, the University of Chicago Colloquium on Classical Antiquity and Modern Institutions in France in 2019, and the Digital Work-in-Progress Seminar hosted by University of Minnesota Center for Early Modern History in 2020. I would like to thank the organizers and participants of these seminars for their insightful comments. I am also deeply grateful to Frederic Clark, Dan Edelstein, Mimi Kim, Alan Charles Kors, Stephanie Malia Hom, Katherine M. Marino, Darrin M. McMahon, Christy L. Pichichero, J. B. Shank, Jacob Soll, and the anonymous reviewers for Modern Intellectual History for their written comments.

Cite this article: Matytsin AM (2022). Enlightenment and Erudition: Writing Cultural History at the Académie des inscriptions. Modern Intellectual History 19, 323-348. https://doi.org/10.1017/ S1479244321000068 